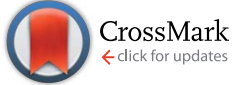

Cite this: RSC Adv., 2015, 5, 43209
Received 13th March 2015 Accepted 8th May 2015

DOI: $10.1039 / c 5 r a 04451 k$

www.rsc.org/advances

\section{Extraction of lithium-ion battery electrolytes with liquid and supercritical carbon dioxide and additional solvents}

\author{
Martin Grützke, Xaver Mönnighoff, Fabian Horsthemke, Vadim Kraft, Martin Winter \\ and Sascha Nowak*
}

\begin{abstract}
A flow-through method for the extraction of lithium-ion battery electrolytes with supercritical and liquid carbon dioxide ( $\mathrm{sc}$ and liq $\mathrm{CO}_{2}$ ) under the addition of different solvents has been developed and optimized to achieve quantitative extraction of the electrolyte from commercial $\mathrm{LiNi}_{1 / 3} \mathrm{Co}_{1 / 3} \mathrm{Mn}_{1 / 3} \mathrm{O}_{2}$ (NMC)/graphite 18650 cells. Furthermore, the time-dependence of the extraction procedure was investigated and demonstrated. The extracts were analyzed with gas and ion chromatography. Linear carbonates like dimethyl carbonate (DMC) and ethyl methyl carbonate (EMC), respectively, were better extracted with liq $\mathrm{CO}_{2}$, whereas the cyclic carbonate ethylene carbonate $(\mathrm{EC})$ was recovered in higher amounts with $\mathrm{sC} \mathrm{CO}_{2}$. The addition of solvents to the $\mathrm{CO}_{2}$ resulted in improved recovery for all the ingredients but most effectively for $\mathrm{LiPF}_{6}$, which could not be obtained by extraction with $\mathrm{CO}_{2}$ only. The best results were achieved by extracting for 30 minutes with liq $\mathrm{CO}_{2}\left(25^{\circ} \mathrm{C}, 60\right.$ bar) and $0.5 \mathrm{~mL} \mathrm{~min}{ }^{-1}$ acetonitrile (ACN)/propylene carbonate (PC) in a mixture of three to one and an additional 20 minutes with liq $\mathrm{CO}_{2}$ only, to yield $(89.1 \pm 3.4) \mathrm{wt} \%$ electrolyte in almost its original composition of DMC, EMC, EC $(1: 1: 1)$ with $1.1 \mathrm{~mol} \mathrm{~L}^{-1} \mathrm{LiPF}_{6}$. Therefore, the presented method can be relevant for the recycling of lithium ion battery electrolytes but has to be validated for up-scaled processes. Furthermore, the suitability of $\mathrm{CO}_{2}$ extraction as a tool for post-mortem or aging investigations of LIB electrolytes could once more successfully be demonstrated due to the extraction of aging products like diethyl-2,5dioxahexane dicarboxylate (DEDOHC) from a pouch cell, which was electrochemically aged for 1000 cycles at $1 \mathrm{C}$. In this context, extraction times and recovery rates were drastically improved compared to our previously reported static extraction experiments.
\end{abstract}

\section{Introduction}

Besides its well-known role as a greenhouse gas in climate change discussions, ${ }^{\mathbf{1 - 4}}$ carbon dioxide also takes part in many chemical reactions. It is for example used in the synthesis of linear ${ }^{5-8}$ and cyclic ${ }^{9}$ organic carbonates, which are, inter alia, solvents for conducting salts, typically $\mathrm{LiPF}_{6},{ }^{10}$ in modern lithium-ion batteries (LIBs). ${ }^{\mathbf{1 1} 12} \mathrm{CO}_{2}$ has also been used as a solid electrolyte interphase $(\mathrm{SEI})^{\mathbf{1 3}}$ forming electrolyte additive in lithium metal and lithium-ion batteries ${ }^{\mathbf{1 4}}$ and is produced when the organic carbonate based electrolyte solvents are oxidized, e.g. during overcharge ${ }^{15}$ in some cases. $\mathrm{CO}_{2}$ is also generated during the reduction of organic carbonate based battery electrolytes. ${ }^{\mathbf{1 6}, 17}$ Furthermore, graphite anode surface modification with $\mathrm{CO}_{2}$ has been performed. ${ }^{18,19}$ Moreover, $\mathrm{CO}_{2}$ is widely applied as a monomer in materials synthesis ${ }^{\mathbf{2 0}}$ or a C-1

University of Münster, MEET Battery Research Center, Institute of Physical Chemistry, Corrensstraße 46, 48149 Münster, Germany.E-mail: sascha.nowak@uni-muenster.de; Fax: +49-251-83 36032 block in the synthesis of polycarbonates ${ }^{21}$ and other organic products. $^{22}$

In addition to its gaseous, liquid and solid phase, carbon dioxide shows a relatively easy available supercritical phase after adjusting temperature and pressure above the critical point which is at $31^{\circ} \mathrm{C}$ and $74 \mathrm{bar}^{23}$ The dissolving properties of sc $\mathrm{CO}_{2}$ are comparably high for many organic substances, especially in combination with additional solvents. Thus, $\mathrm{CO}_{2}$ is the most applied extraction medium in supercritical fluid extraction (SFE). ${ }^{24}$ The most prominent example for the application of $\mathrm{sc} \mathrm{CO}_{2}$ extraction might be the decaffeination process of coffee. ${ }^{25,26}$ Likewise, sc $\mathrm{CO}_{2}$ is generally used a lot as extraction medium in food chemistry. ${ }^{27-29}$ Furthermore, its usage as eluent is also important in supercritical fluid chromatography (SFC), ${ }^{24}$ as drying agent in crack free silica aerogel production $^{30,31}$ and as reaction medium in olefin polymerization reactions $^{32}$ or metal nanoparticle synthesis. ${ }^{33}$

Sloop et al. described the extraction of electrolytes from energy storage devices with supercritical fluids. ${ }^{34}$ LIBs were mentioned in this patent but detailed information about the extraction behavior were rare. LIBs are the most applied energy 
storage systems for modern consumer and portable electronics like smartphones and cameras, and the most promising battery technology for electric or hybrid electric vehicles. ${ }^{35,36}$ LIBs usually consist of a graphitic anode and a transition metal oxide $^{77}$ or phosphate cathode ${ }^{78}$ with a polymeric or ceramic separator in between. A non-aqueous aprotic electrolyte serves for charge transfer in form of lithium-ions. Electrolytes for LIBs are made of different linear carbonates (e.g. dimethyl carbonate (DMC) and ethyl methyl carbonate (EMC)) in a mixture with ethylene carbonate (EC). ${ }^{11,12,37} \mathrm{LiPF}_{6}$ is generally used as conducting salt and dissolved in this solution in concentrations of about $1 \mathrm{~mol} \mathrm{~L}^{-1}$. Moreover, additives for various electrolyte properties can be present. $^{38,39}$ Dimethyl methylphosphonate can be applied as flame retardant, ${ }^{40}$ cyclohexylbenzene for overcharge protection ${ }^{\mathbf{1 1}}$ and vinylene carbonate as film forming additive for controlled formation of the SEI. ${ }^{11,12,41-46}$

Different aging processes occur in LIBs which lead to a creeping loss of capacity and a limited cell lifetime. ${ }^{47}$ One of these aging effects is the decomposition of the electrolyte during cycling which is furthermore influenced by the temperature and the quality of each and every compound in the cell, especially with regards to protic impurities. Research on electrolyte decomposition as well as the development of new and specific analytical methods has been done in recent years, ${ }^{38,48-67}$ but there is still a far way to go until the complete picture of electrolyte aging in LIBs is fully understood. Furthermore, the quantitatively extraction from the LIBs is of interest for recycling processes. Since $50 \mathrm{wt} \%$ of a cell has to be recovered, the electrolyte represents a target component for the recycling of LIBs. Additionally, fluoride or fluorinated compounds can hamper or damaged industrial scaled recycling processes and have to be removed as well.

We recently reported the extraction of LIB electrolytes with supercritical helium head pressure carbon dioxide $\left(\mathrm{sc} \mathrm{HHPCO}_{2}\right)$ in a simple autoclave setup. ${ }^{63}$ A successful proof of principle experiment was demonstrated. Furthermore, the sc $\mathrm{HHPCO}_{2}$ extraction could be presented as sample preparation tool for LIB post-mortem aging investigations. $\mathrm{HHPCO}_{2}$ was used in these experiments to keep the experimental equipment as easy as possible. $\mathrm{Sc} \mathrm{CO}_{2}$ conditions can be achieved without a compressor already from the bottle. Nevertheless, $\mathrm{HHPCO}_{2}$ is more expensive than conventional liq $\mathrm{CO}_{2}$ with the same purity. Furthermore, the recovery rate for the electrolyte from the investigated 18650 cells was relatively low ( $<10 \mathrm{wt} \%)$. Moreover, it was not possible to obtain the conducting salt but only the organic carbonates. To overcome these drawbacks and to further investigate the extraction of LIB electrolytes with $\mathrm{CO}_{2}$ we installed a conventional flow-through SFE extraction unit. Herein, we report the results for the extraction of commercial 18650 cells $(2.2 \mathrm{Ah})$ as well as in-house-made pouch cells (4.8 Ah), both based on $\mathrm{LiNi}_{1 / 3} \mathrm{Co}_{1 / 3} \mathrm{Mn}_{1 / 3} \mathrm{O}_{2}$ (NMC)/graphite electrode chemistry, with liquid and supercritical carbon dioxide regarding the recovery rate of the particular electrolyte components, additional solvents in the $\mathrm{CO}_{2}$-stream and the time dependency of the extraction procedure. Since, one investigation was the recycling and aging of LIBs, we decided to use electrolytes which are state-of-the-art in commercial applied LIBs. Nevertheless, it is still possible to investigate alternative systems.

\section{Experimental}

\subsection{Chemicals and materials}

Panasonic CGR18650CH Li-ion MH12210 (2.2 Ah, NMC/ graphite) were bought from BattEnergy. 18650 cells are often used for safety investigations, ${ }^{68-70}$ and are generally applied in laptops and E-bikes. 4.8 Ah NMC/graphite pouch cells were fabricated with an in-house battery line. Anhydrous acetronitrile (ACN) (99.8\%) from Sigma-Aldrich, and dry and fresh battery grade diethyl carbonate (DEC; 99.9\%) and propylene (PC) (99.9\%) from BASF were used for solvent addition in the $\mathrm{CO}_{2}$ extraction experiments. DMC (99.9\%), EMC (99.0\%), DEC (99.9\%) and EC (99.9\%) for gas chromatography (GC) experiments, tartaric acid (99.5\%), dipicolinic acid (99.0\%), $\mathrm{Na}_{2} \mathrm{CO}_{3}$ (Certipur), $\mathrm{NaHCO}_{3}(99.7 \%)$ and $\mathrm{H}_{2} \mathrm{SO}_{4}\left(0.1 \mathrm{~mol} \mathrm{~L}{ }^{-1}\right)$ were purchased from Merck. Aqueous lithium standard solution (TraceCert IC standard, $1 \mathrm{~g} \mathrm{~L}^{-1} \mathrm{Li}^{+}, \leq 0.1 \% \mathrm{HNO}_{3}$ ) and aqueous fluoride standard solution (TraceCert IC standard, $1 \mathrm{~g} \mathrm{~L}^{-1} \mathrm{NaF}$ ) were supplied by Fluka. ACN (99.9\%, HiPerSolv CHROMANORM, LC-MS grade) from VWR and Milli Q water, produced with an in-house Millipore filter system were used for sample dilution. $\mathrm{CO}_{2}$ (purity 5.0) for SFE and helium (purity 6.0) for GC experiments were purchased from Westfalen Gas.

\subsection{Cell cycling procedures}

The pouch cells were cycled with a Maccor Series 4000 Battery Tester 20A in an environmental test chamber (Binder KB 400) at $20{ }^{\circ} \mathrm{C}$. The cells were charged with $0.2 \mathrm{C}$ in constant current mode up to a voltage of $4.2 \mathrm{~V}$, followed by a constant voltage step at $4.2 \mathrm{~V}$ for $30 \mathrm{~min}$. The discharge was performed with $1 \mathrm{C}$ in constant current mode down to a voltage of $3.0 \mathrm{~V}$. Subsequently, the cell was charged and discharged with $1 \mathrm{C}$ (constant current) between $3.0 \mathrm{~V}$ and $4.2 \mathrm{~V}$ for 1000 cycles. Before opening the cells an extended discharge step was carried out, composed of successive and decreasing constant current steps each until a voltage of $3.0 \mathrm{~V}$ and constant rest periods between the discharge steps.

\subsection{Sample preparation}

The discharged cells (18 650 and pouch) were frozen at $-18{ }^{\circ} \mathrm{C}$ for at least $10 \mathrm{~h}$, so that electrolyte evaporation during cell opening is reduced to a minimum, and subsequently opened in a glove box $\left(\mathrm{O}_{2}, \mathrm{H}_{2} \mathrm{O}<0.1 \mathrm{ppm}\right)$ by slicing the two ends of the metal shell with an industrial cutter (18 650 cells), similar to the self-made cutter of Aurbach et al.,$^{71}$ or by cutting the outer pouch foil with ceramic scissors (pouch cells). The jelly role as well as the stack, were removed of the shell, uncoiled and put, as dense as possible, into the pressure chamber of the extraction equipment. 


\subsection{Extraction procedure}

After connecting the extraction chamber to the $\mathrm{CO}_{2}$ supply and adjusting pressure and temperature in the chamber to extraction conditions (liquid: $25{ }^{\circ} \mathrm{C}, 60$ bar; supercritical: $40{ }^{\circ} \mathrm{C}$, 300 bar), the experiment begun with a static (non-flow-through) equilibration step which was hold for $30 \mathrm{~min}$, followed by $2 \mathrm{~min}$ of $\mathrm{CO}_{2}$ flow-through with subsequent $5 \mathrm{~min}$ static (non-flowthrough) equilibration, in which the amount of collected extract was weighted (experiments in Fig. 1 and 2). The outlet valve of the $\mathrm{CO}_{2}$-extraction-stream was heated to $55^{\circ} \mathrm{C}$ and the electrolyte was collected with a cryogenic trap of aluminum $\left(-78^{\circ} \mathrm{C}\right)$ behind the outlet valve.

For the results in Fig. 3-6, additional solvent (ACN, DEC, PC) with a flow of $0.5 \mathrm{~mL} \mathrm{~min}{ }^{-1}$ was added to the $\mathrm{CO}_{2}$-stream. After an equilibration step of $30 \mathrm{~min}$ at the beginning with $\mathrm{CO}_{2}$, but without solvent, it was extracted in flow-through for two minutes with subsequent 5 min of static equilibration time. The

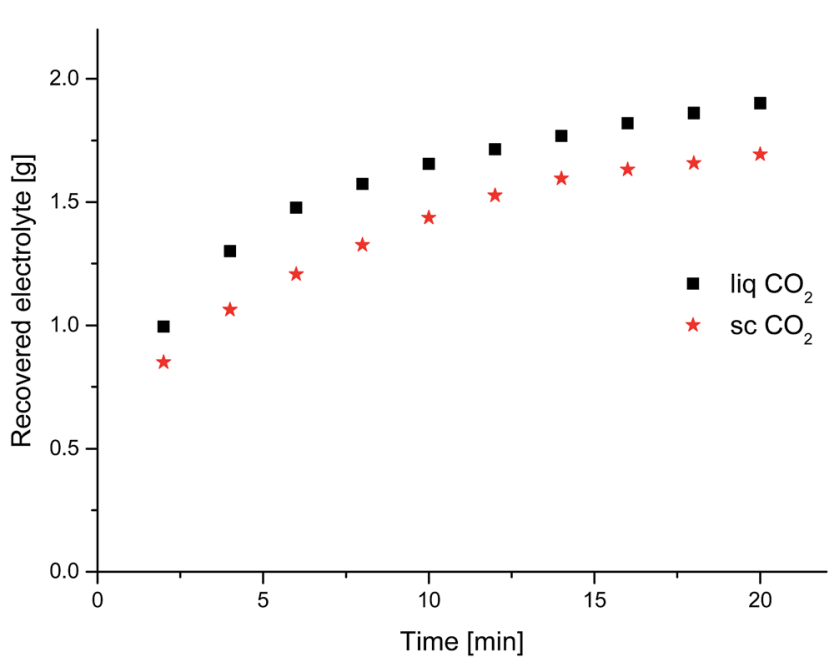

Fig. 1 Time dependency of the amount of recovered electrolyte from commercial 18650 cells after formation extracted with supercritical (300 bar, $40{ }^{\circ} \mathrm{C}$; red stars) and liquid (60 bar, $25^{\circ} \mathrm{C}$; black squares) $\mathrm{CO}_{2}$.
$(2+5)$ min step was repeated 15 times, followed by 20 min flowthrough extraction without solvent $\left(\right.$ only $\left.\mathrm{CO}_{2}\right)$.

\subsection{Analytical equipment}

Supercritical fluid extraction (SFE) unit. All extraction experiments were done in a dry room (dew point: $-65{ }^{\circ} \mathrm{C} ; \mathrm{H}_{2} \mathrm{O}<$ $5.4 \mathrm{ppm}$ ). An Applied Separations Spe-ed SFE System purchased from ERC, which is equipped with a Knauer Platin Blue UHPLC pump for solvent addition, was used for the extraction experiments. The extraction chamber $(50 \mathrm{~mL}$ for 18650 cells and $100 \mathrm{~mL}$ for pouch cells) and all gas lines consist of stainless steel. At the beginning of each extraction experiment, the device was investigated for gas leaks. Furthermore, the $\mathrm{CO}_{2}$ flow was adjusted to $(15 \pm 3) \mathrm{L} \mathrm{min}^{-1}$.

Ion chromatography (IC). A Metrohm 850 Professional IC with conductivity detection, an 889 IC Sample Center and the Magic Net 2.2 software was used. Samples were diluted appropriately with water for cation analysis to $\mathrm{a} \mathrm{Li}^{+}$concentration between 1-25 $\mathrm{mg} \mathrm{kg}^{-1}$ and $10 \mu \mathrm{L}$ were injected. An aqueous eluent with $4 \mathrm{mmol} \mathrm{L}^{-1}$ tartaric acid and $0.75 \mathrm{mmol} \mathrm{L}^{-1}$ dipicolinic acid (which is also used as chelate ligand for heptacoordinated $\mathrm{Ti}^{\mathrm{IV}}$ complexes $)^{72}$ was used with a flow of $0.7 \mathrm{~mL}$ $\min ^{-1}$ on a Metrosep C 4-150/4.0 + Metrosep C 4 Guard/4.0 column at a temperature of $40{ }^{\circ} \mathrm{C}$. $\mathrm{Li}^{+}$was quantified applying an external six-point calibration $\left(R^{2}>0.9999\right)$ in a range between $0.2 \mathrm{mg} \mathrm{kg} \mathrm{kg}^{-1}$ to $25 \mathrm{mg} \mathrm{kg}{ }^{-1}$. Each point and sample was measured two times. The limit of detection (LOD) and the limit of quantification (LOQ) for $\mathrm{Li}^{+}$and the applied conditions according to DIN 32645 are $162 \mu \mathrm{g} \mathrm{kg}{ }^{-1}$ and $604 \mu \mathrm{g} \mathrm{kg} \mathrm{kg}^{-1}$, respectively.

Samples were diluted $1: 10$ to $1: 50$ with water for anion analysis and $20 \mu \mathrm{L}$ were injected. An aqueous eluent with $1.8 \mathrm{mmol} \mathrm{L}^{-1} \mathrm{Na}_{2} \mathrm{CO}_{3}$ and $1.7 \mathrm{mmol} \mathrm{L}{ }^{-1} \mathrm{NaHCO}_{3}$ was used with a flow of $1 \mathrm{~mL} \min ^{-1}$ on a Metrosep A Supp 4-250/4.0 + Metrosep A Supp $4 / 5$ Guard $/ 4.0$ column at a temperature of $40{ }^{\circ} \mathrm{C}$. After $10 \mathrm{~min}$, a gradient step was applied and over $3 \mathrm{~min}$, ACN was added up to a concentration of $50 \mathrm{vol} \%$. $\mathrm{F}^{-}$could be confirmed via the retention time of a standard solution. $\mathrm{PO}_{2} \mathrm{~F}_{2}{ }^{-}, \mathrm{PF}_{6}{ }^{-}$and
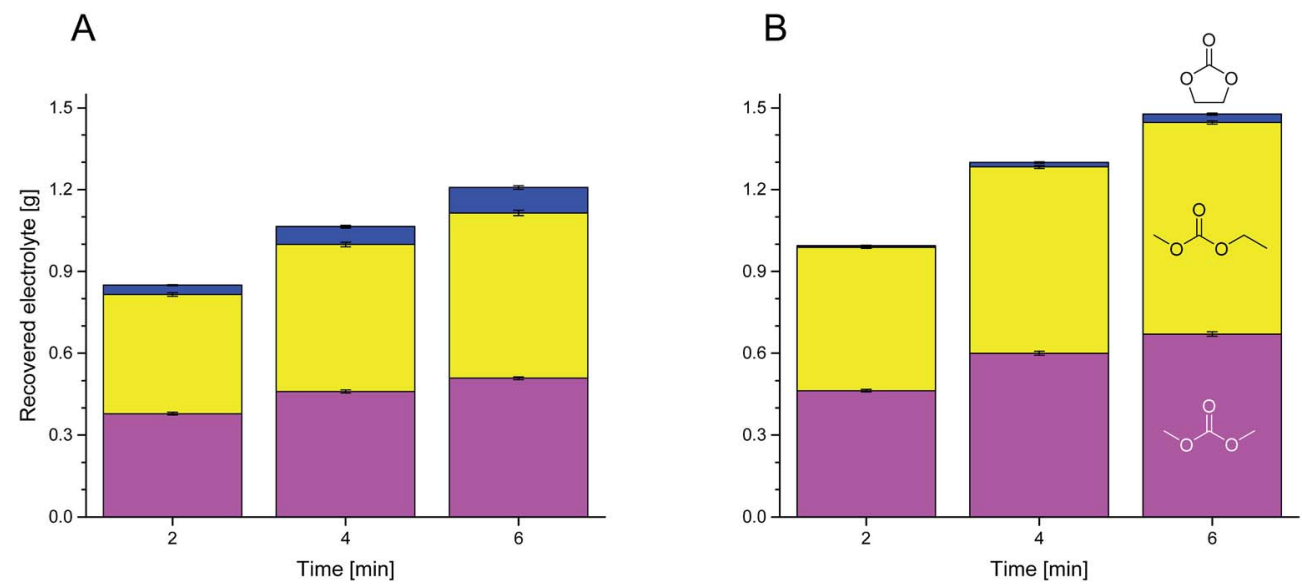

Fig. 2 Compositions of the recovered electrolyte from commercial 18650 cells after formation extracted with supercritical (A) and liquid (B) CO 2 for the first three data points of Fig. 1 determined with GC-MS. Blue, top: EC; yellow, middle: EMC; magenta, bottom: DMC. 


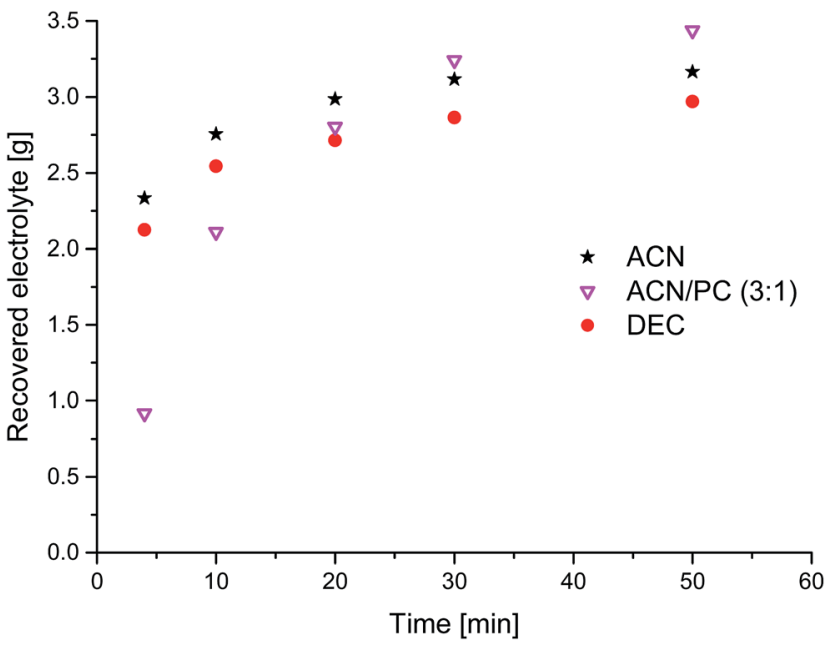

Fig. 3 Time dependency of the amount of recovered electrolyte from commercial 18650 cells after formation extracted with liquid $\mathrm{CO}_{2}$ and

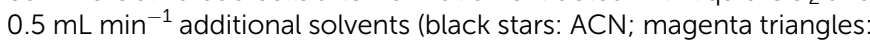
$A C N-P C(3: 1)$; red circles: DEC).

alkyl fluoro phosphates were identified with IC hyphenated to electrospray ionization-mass spectrometry (ESI-MS). Equipment, procedure and conditions were recently published and applied. ${ }^{60,64,65}$

Gas chromatography-mass spectrometry (GC-MS). A Shimadzu GCMS-QP2010 Ultra GC-MS equipped with an AOC-5000 Plus autosampler, an OPTIC-4 injection system and a Supelco SLB- $5 \mathrm{~ms}$ column $(30 \mathrm{~m} \times 0.25 \mathrm{~mm} \times 0.25 \mu \mathrm{m})$ was used. The GCMS Solution software (GCMS Real Time Analysis and GCMS Postrun Analysis) and the Evolution Workstation software were used for setup control and data analysis. DMC, EMC, DEC, PC, vinylene carbonate (VC) and EC could clearly be identified with the National Institute of Standards (NIST) 08 library and DEDOHC with chemical ionization GC-MS experiments. ${ }^{63}$ The results could be confirmed via the retention time of the corresponding pure substances. $1 \mu \mathrm{L}$ of the diluted samples $(1: 100$, ACN) was injected at an injection temperature of $230{ }^{\circ} \mathrm{C}$. The system was run with helium as carrier gas with a column flow of

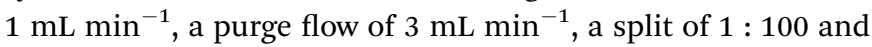
the following column oven program: starting with $40{ }^{\circ} \mathrm{C}$ for 2 min, the temperature was increased with a rate of $30{ }^{\circ} \mathrm{C} \mathrm{min}{ }^{-1}$ to $230{ }^{\circ} \mathrm{C}$ and held for $2.67 \mathrm{~min}$. It was measured in the electron ionization (EI) mode at an ion source temperature of $200{ }^{\circ} \mathrm{C}$, a filament voltage of $70 \mathrm{~V}$, a detector voltage, which was chosen relative to the particular tuning result $(\sim 1 \mathrm{kV})$ in a range of $25-$ $300 \mathrm{~m} / \mathrm{z}$ with an event time of $0.1 \mathrm{~s}$ and a GC-MS interface temperature of $250{ }^{\circ} \mathrm{C}$.

Quantitative results were obtained with appropriate dilution of the samples to be within the external five-point calibration $\left(R^{2}>0.999\right)$ in a range of $10 \mathrm{mg} \mathrm{kg}^{-1}$ to $1500 \mathrm{mg} \mathrm{kg}{ }^{-1}(10 \mathrm{mg}$ $\mathrm{kg}^{-1}$ to $100 \mathrm{mg} \mathrm{kg}^{-1}$ for DEDOHC) under the same GC-MS conditions as just described but with single ion monitoring (SIM) via the following ions: DMC $(59 \mathrm{~m} / \mathrm{z})$, EMC $(77 \mathrm{~m} / \mathrm{z})$, DEC $(91 \mathrm{~m} / \mathrm{z})$, PC $(102 \mathrm{~m} / \mathrm{z})$, EC $(88 \mathrm{~m} / \mathrm{z})$ and DEDOHC $(89 \mathrm{~m} / \mathrm{z})$. Each sample and concentration was measured two times. Limits of detection (LOD) and limits of quantification (LOQ) were determined according to DIN 32645: DMC (31.7 $\mathrm{mg} \mathrm{L}^{-1}, 121.0 \mathrm{mg}$ $\mathrm{kg}^{-1}$ ), EMC (14.9 $\mathrm{mg} \mathrm{kg}^{-1}, 56.9 \mathrm{mg} \mathrm{kg}^{-1}$ ), DEC (12.0 mg kg ${ }^{-1}$, $\left.46.3 \mathrm{mg} \mathrm{kg}^{-1}\right)$, PC (11.7 mg kg $\left.{ }^{-1}, 49.4 \mathrm{mg} \mathrm{kg}^{-1}\right)$, EC (13.3 mg $\mathrm{kg}^{-1}, 51.1 \mathrm{mg} \mathrm{kg}^{-1}$ ) and DEDOHC (3.6 mg kg $\left.{ }^{-1}, 14.0 \mathrm{mg} \mathrm{kg}^{-1}\right)$.

\section{Results and discussion}

First of all, it was necessary to develop a suitable extraction method to extract and collect a LIB electrolyte with the Applied Separations Spe-ed SFE System extraction equipment. We started by putting a LIB electrolyte (each experiment the same amount) containing polyethylene fleece separator into the extraction chamber of the extraction equipment. For the development of an appropriate collection method, the sample was always extracted under the same supercritical conditions: $40{ }^{\circ} \mathrm{C}, 80$ bar $\mathrm{CO}_{2}$ in flow-through mode for one hour. The outlet valve of the extraction device is heated, which is necessary due to the Joule-Thomson-Effect. ${ }^{73}$ This temperature was set to $55{ }^{\circ} \mathrm{C}$ because of the possible thermal decomposition of $\mathrm{LiPF}_{6}$ at higher temperature. ${ }^{74}$ It was proven, that collecting the electrolyte from the $\mathrm{CO}_{2}$-stream during pressure relaxation with a cryogenic trap (aluminum vial at $-78{ }^{\circ} \mathrm{C}$ ) resulted in better recovery of the electrolyte than washing solutions with different organic solvents (e.g. ACN). Furthermore, it is advisable to pack the sample in the extraction chamber as dense as possible to get good extraction results, otherwise the $\mathrm{CO}_{2}$, as extraction medium, just passes by the sample without leaching it.

After adjusting these first parameters, further method development was done with $2.2 \mathrm{Ah}$, NMC/graphite commercial 18650 cells (Panasonic CGR18650CH Li-ion MH12210). The uncoiled jelly roll was densely packed into the extraction chamber. Variation of the pressure at supercritical extraction conditions $\left(40{ }^{\circ} \mathrm{C}, 80\right.$ bar vs. 300 bar) resulted only in slightly different recovery rates at the same $\mathrm{CO}_{2}$ flow, whereas variation of the flow at the same pressure gave much higher recovery rates (by weight) in the same time. Unfortunately this parameter was limited due to the mentioned Joule-Thomson-Effect because $\mathrm{CO}_{2}$ simply freezes out in the cryogenic trap when the flow is too high. Thus, the flow was adjusted to $15 \mathrm{~L} \mathrm{~min}^{-1}$ at the outlet valve for all further experiments as good compromise between high flow rate (which means short extraction times) and resublimating $\mathrm{CO}_{2}$. The $\mathrm{CO}_{2}$ flow control of the outlet valve over time showed, that the used extraction equipment could not better be adjusted than within $20 \%$ relative standard deviation which means a $\mathrm{CO}_{2}$ flow of $(15 \pm 3) \mathrm{L} \mathrm{min}^{-1}$.

Two different $\mathrm{CO}_{2}$ conditions were compared. While extracting with liq $\mathrm{CO}_{2}\left(25^{\circ} \mathrm{C}, 60\right.$ bar $)$, we reproducibly achieved a higher amount of extracted electrolyte at the same extraction time and volumetric flow as with $\mathrm{sc}^{\mathrm{CO}_{2}}\left(40{ }^{\circ} \mathrm{C}, 300\right.$ bar $)$. This may be explained by differences due to the flow behavior of liquid $\mathrm{CO}_{2}$ compared to $\mathrm{sc} \mathrm{CO}_{2}$ (laminar vs. non-laminar). We further investigated this behavior in a time-resolved experiment (Fig. 1), which confirmed our results. Most of the extracted amount is obtained in the first minutes. Also the better recovery with liq $\mathrm{CO}_{2}$ already happens at the beginning of the extraction. The demonstrated data show exponential behavior over time. 


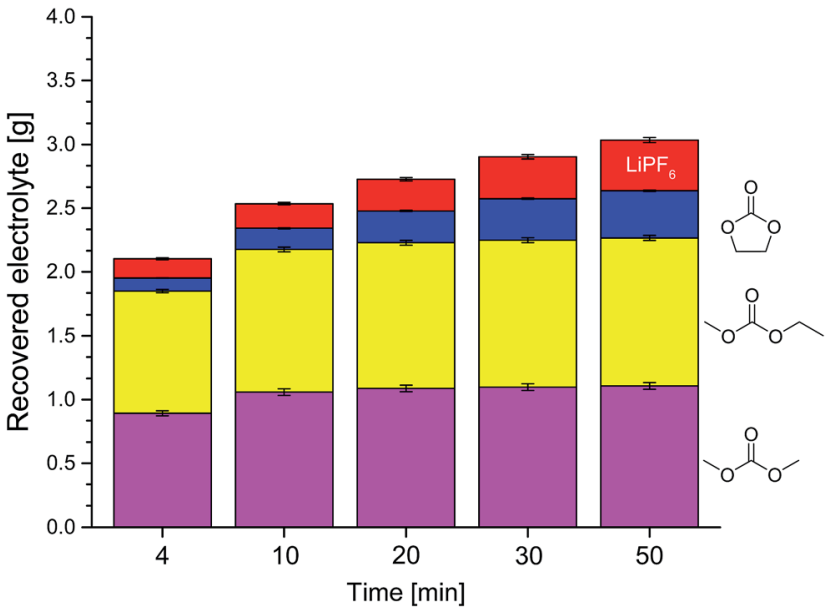

Fig. 4 Compositions of the recovered electrolyte from commercial 18650 cells after formation extracted with liquid $\mathrm{CO}_{2}$ and additional DEC in the $\mathrm{CO}_{2}$-stream determined with GC-MS and IC corresponding to Fig. 3. Red, top: LiPF 6 ; blue, below: EC; yellow, middle: EMC; magenta, bottom: DMC.

and therefore the deviation during. Analyses of the extracts of the first minutes with GC-MS reveal that the linear carbonates, DMC and EMC, are extracted with higher efficiency than EC (Fig. 2). Interestingly, the higher amount which is achieved with liq $\mathrm{CO}_{2}$ is only linear carbonates. Compared to liq $\mathrm{CO}_{2}$, extraction with $\mathrm{sc} \mathrm{CO}_{2}$ is better suited for EC. $\mathrm{CO}_{2}$ is a relatively nonpolar extraction medium ${ }^{26}$ which explains why the more polar EC (dipole moment: $4.61 \mathrm{D}$ ) is less well extracted than DMC $(0.76 \mathrm{D})$ and EMC $(0.89 \mathrm{D}) .{ }^{11}$ This nonpolarity is also the reason for the poor extraction of the conducting salt which could only be gained in trace amounts (as confirmed by IC), which was also observed for the extraction of the same 18650 cells with sc $\mathrm{HHPCO}_{2}$ with a different experimental setup. ${ }^{63}$ The amount of electrolyte in the investigated 18650 cells was determined to $3.76 \mathrm{~g}$ by drying an opened cell at $120{ }^{\circ} \mathrm{C}$ in vacuum over 10 hours. We concluded that this amount could not be reached under the so far applied extraction conditions. Only the linear carbonates could quantitatively be recovered after a very long extraction time (over $3 \mathrm{~h}$ ).

To overcome (i) these drawbacks of long extraction times, (ii) the small concentration of EC and (iii) the not extracted conducting salt, extraction experiments with added solvents to the liq $\mathrm{CO}_{2}$ were realized. The time-resolved results for three different additional solvents are summarized in Fig. 3. The exponential behavior ends at $50 \mathrm{~min}$ of extraction time at recovery rates which are much higher compared to extraction with sc $\mathrm{CO}_{2}$ or liq $\mathrm{CO}_{2}$ without additional solvents. The experiments with ACN and DEC show a similar trend with high recovery rates in the first minutes compared to the ACN/PC mixture, which leads to an indolent extraction at first, but finishes with the best overall result. An experiment with only PC as added solvent was also carried out but the collected extract was with about $2 \mathrm{~g}$ after the applied extraction method of $50 \mathrm{~min}$ much less than the three scenarios demonstrated in Fig. 3. Furthermore, a large amount of the PC apparently remained in the solid battery material during this time, which could be confirmed by weight and also by the 'wet' solid battery material after the extraction chamber was opened for cleaning purposes subsequent to the extraction experiment. Thus, it can be concluded that the addition of very polar solvents (dipole moment PC: $4.81 \mathrm{D})^{\mathbf{1 1}}$ is only reasonable when additional solvents with medium polarity are present, that act as "moderator" between very polar solvent and the rather unpolar $\mathrm{CO}_{2}$.

Fig. 4 shows the compositions of the extracts over the whole period of extraction with DEC as additional solvent. The trend is identical to the extraction process without additional solvent. The linear carbonates (DMC and EMC) are extracted well in the first minutes, but the absolute amount is almost doubled compared to extraction with $\mathrm{CO}_{2}$ only. Furthermore, also high recoveries of EC and even of the conducting salt $\mathrm{LiPF}_{6}$ could be achieved. Fig. 5 demonstrates the GC-MS measurements

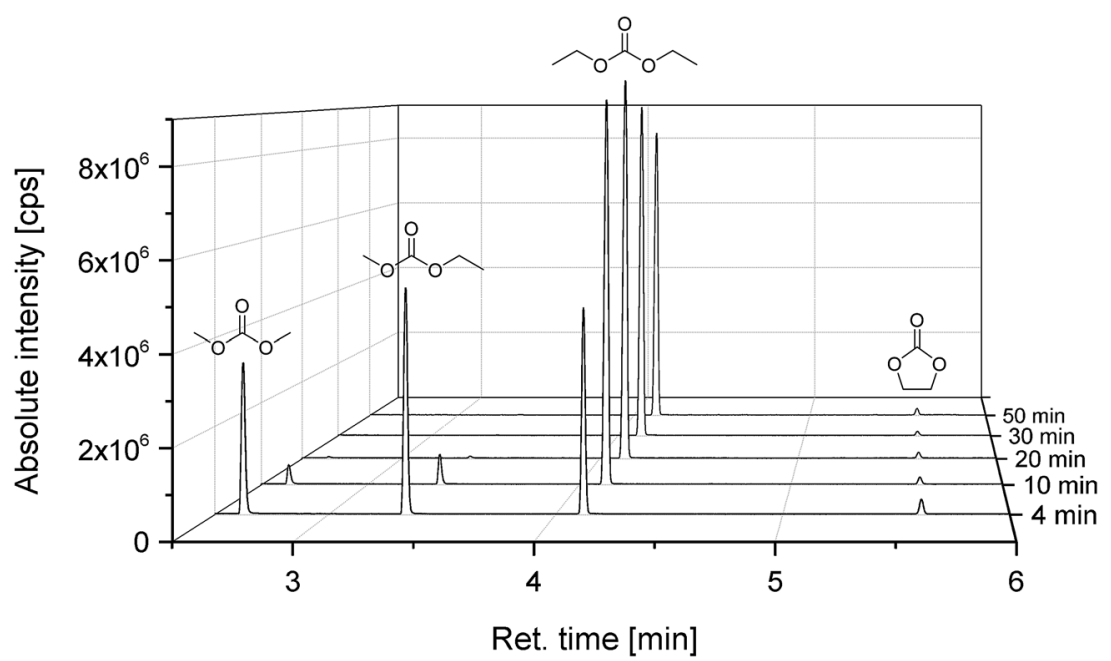

Fig. 5 Chromatograms (GC-MS) of the time-resolved electrolyte recovery which was extracted with liquid $\mathrm{CO}_{2}$ and additional $\mathrm{DEC}$, corresponding to Fig. 3 and 4 . 


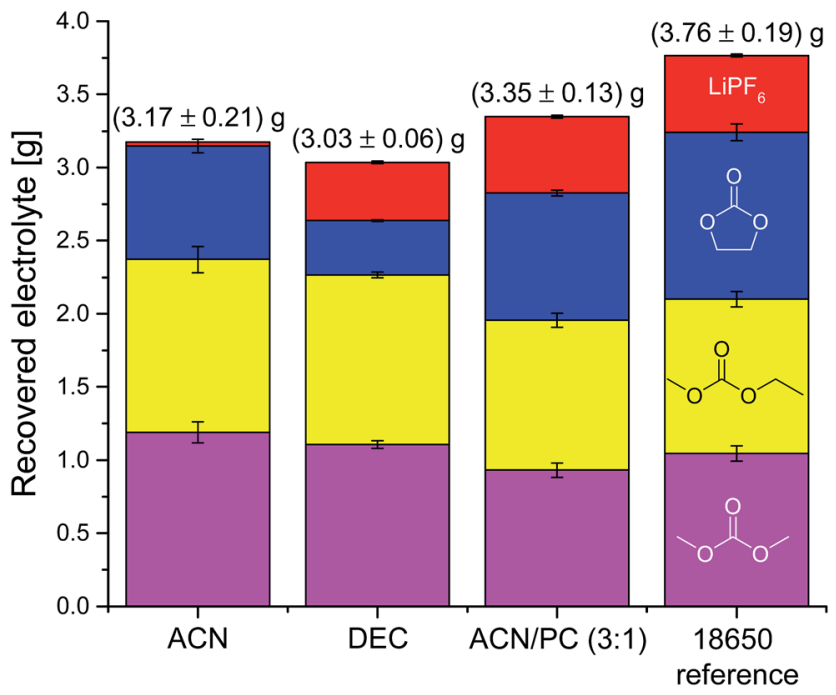

Fig. 6 Compositions and amounts (determined with GC-MS and IC) of the recovered electrolytes from commercial 18650 cells after formation extracted with liquid $\mathrm{CO}_{2}$ and additional solvents for $30 \mathrm{~min}$, with subsequent 20 min without additional solvent. Red, top: LiPF 6 ; blue, below: EC; yellow, middle: EMC; magenta, bottom: DMC.

corresponding to the compositions of the volatile components in Fig. 4. It can be seen that the linear carbonates are only significantly extracted in the first $20 \mathrm{~min}$, whereas EC is present in the same magnitude till the end of the extraction experiment. Fig. 6 summarizes the amounts of recovered electrolyte and their compositions for the three discussed scenarios (see Fig. 3). Additionally, the composition of a reference electrolyte is shown. The reference data are the result of the quantitative investigation of electrolyte $(10 \mu \mathrm{L})$ which was collected during cell opening. The resulted weight percentages are normalized to the amount of electrolyte per 18650 cell. In all cases of extraction with liq $\mathrm{CO}_{2}$ and additional solvents, the linear carbonates could be recovered quantitatively within the limits of error; EC

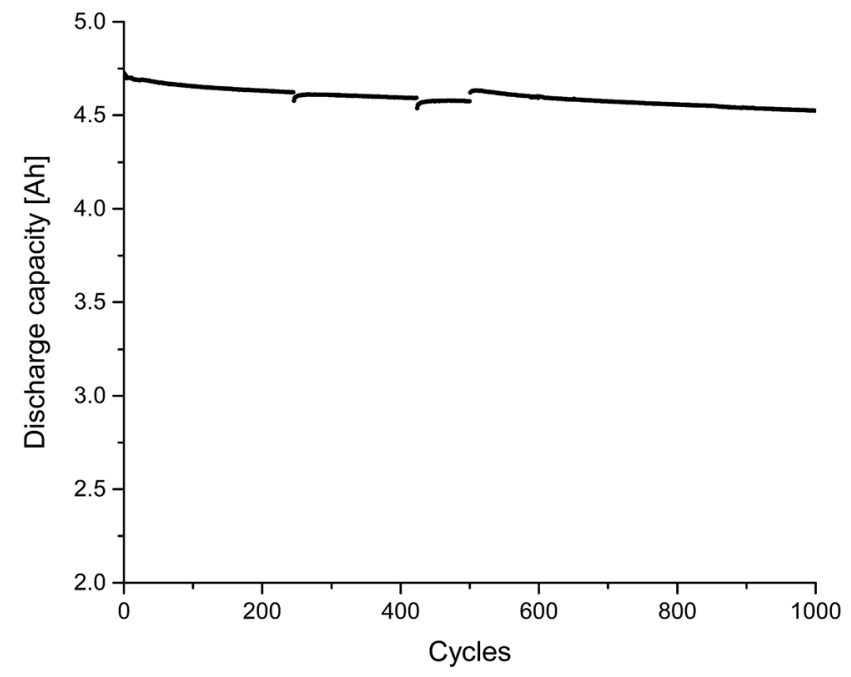

Fig. 7 Discharge capacities for an in-house-made 4.8 Ah pouch cell (cycled at room temperature at a rate of $1 \mathrm{C}$ between $3.0 \mathrm{~V}$ and $4.2 \mathrm{~V}$ ).
Table 1 Composition (wt\%) of the reference electrolyte applied in pouch cells determined with GC-MS and IC

\begin{tabular}{lllll}
\hline DEC & PC & EC & VC & LiPF $_{6}$ \\
\hline $46.9 \pm 2.2$ & $4.5 \pm 0.1$ & $32.4 \pm 0.7$ & $2.0 \pm 0.1$ & $11.7 \pm 0.3$ \\
\hline
\end{tabular}

and $\mathrm{LiPF}_{6}$ could be retrieved at least qualitatively. The best overall recovery rate was achieved for the added ACN/PC mixture, with $(89.1 \pm 3.4) \mathrm{wt} \%$ and furthermore with the highest concentrations for EC and $\mathrm{LiPF}_{6}$.

Finally, we also investigated self-made pouch cells (graphite/ NMC) after formation and after "electrochemical aging", which were bigger than the so far used 18650 cells ( $4.8 \mathrm{Ah} v s .2 .2 \mathrm{Ah}$ ). The results of the cycling experiment (=electrochemical aging) for 1000 charge/discharge cycles at a rate of $1 \mathrm{C}$ are displayed in Fig. 7. An electrolyte consisting of $1 \mathrm{~mol} \mathrm{~L}^{-1} \mathrm{LiPF}_{6}$ in a DEC, PC, EC, VC mixture was applied (quantitative composition see Table 1). All components, except VC, could be detected in the extract, which was achieved with liq $\mathrm{CO}_{2}$ and $\mathrm{ACN}$ as additional solvent. PC as additional solvent was not applied in this case due to its presence in the cells and therefore possible difficulties in quantification of the extract. VC had presumably been consumed during the formation cycle and thus been involved in the SEI formation. ${ }^{11,55}$ In addition to the deployed electrolyte components, DEDOHC, which is an electrolyte aging product, whose formation was already intensively discussed in literature, ${ }^{48,51,54-58,63,66}$ could clearly be identified. This confirms the result of our previous study, that $\mathrm{CO}_{2}$ can be applied as extraction agent for post-mortem or aging investigations. Fig. 8 shows the GC-MS chromatograms corresponding to the aged cell and, consequently, the extract compositions of the collected fractions. The same picture was achieved for the cell after formation. The findings for DEC, EC and PC are in good agreement to the results of the 18650 cells.

DEDOHC could be extracted from the cells after formation and cycling, in the same amount of $(0.4 \pm 0.1) \mathrm{wt} \%$ within the first four minutes. Therefore, it is concluded, that DEDOHC is

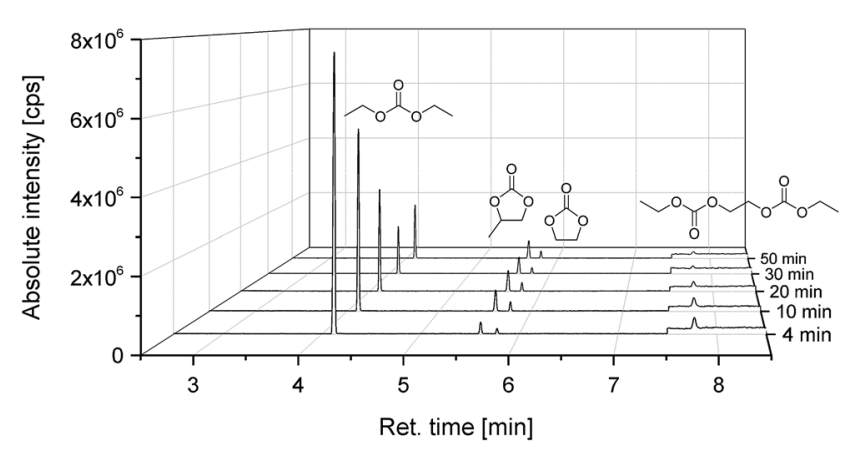

Fig. 8 Chromatograms (GC-MS) of the time-resolved electrolyte recovery from a cycled (=electrochemically aged) pouch cell (Fig. 7) which was extracted with liquid $\mathrm{CO}_{2}$ and additional $\mathrm{ACN}$. The absolute intensity is amplified by one order of magnitude for the last minute of retention time. 
only formed during formation. The 18650 cell showed a different aging behavior in this case. The concentrations of DEDOHC and its derivatives were in correlation with an ongoing film growth during cycling. ${ }^{63}$ The reason for this difference could be the presence or absence, respectively of VC as electrolyte additive for controlled SEI formation. ${ }^{11}$ On the other hand, the pouch cells showed a state-of-health ( $\mathrm{SOH}$ ) of over $97 \%$ after 1000 cycles (Fig. 7), compared to $70 \% \mathrm{SOH}$ for the 18650 cells, which makes a quantitative comparison of the two cell types difficult.

Moreover, we could detect traces of decomposition products of the conducting salt $\mathrm{LiPF}_{6}$, such as $\mathrm{F}^{-}, \mathrm{PO}_{2} \mathrm{~F}_{2}{ }^{-}$and different fluoro phosphates with IC and IC hyphenated to electrospray ionization mass spectrometry (ESI-MS) in all samples, even for the cells, which were extracted without additional solvents. This confirms once more the suitability of $\mathrm{CO}_{2}$ extraction as sample preparation tool for post-mortem or aging investigations of LIB electrolytes.

\section{Conclusions}

The extraction behavior of supercritical and liquid carbon dioxide with and without additional solvents has been investigated in flow-through experiments regarding the recovery of electrolytes from lithium-ion batteries. The extracts were analyzed with GC-MS and IC for their compositions. For an

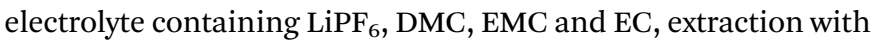
liq $\mathrm{CO}_{2}$ resulted in higher recovery for linear carbonates (DMC, EMC) and lower for EC but in a higher overall yield compared to extraction with $\mathrm{sc} \mathrm{CO}_{2}$. The extraction of the electrolyte ingredients was improved by application of additional solvents to the $\mathrm{CO}_{2}$ and, furthermore, also $\mathrm{LiPF}_{6}$ was extracted. Maximum recovery rates were achieved with mixtures of different solvents. It was demonstrated, that the electrolyte of a Panasonic 18650 cell was recovered in $(89.1 \pm 3.4) \mathrm{wt} \%$ almost quantitatively with liq $\mathrm{CO}_{2}$ and ACN-PC $(3: 1)$ as additional solvents. Thus, we conclude, that it is generally possible to apply $\mathrm{CO}_{2}$ extraction to used battery cell electrolytes by properly adjusting the extraction conditions (especially the additional solvents) to the individual cell components (electrode materials, separator, electrolyte and geometry) which should be extracted. This promising procedure could be an alternative for distortion of the electrolyte in LIB recycling, ${ }^{75}$ and even for solvent extraction. ${ }^{76}$ However, the developed method is a suitable tool for LIB electrolyte and postmortem or aging investigations because a qualitative overview can already be achieved after a few minutes of extraction also for apparently 'dry' cells, where the electrolyte is deeply penetrated in the solid battery material. The application of this tool for a screening of different aged cells from several battery suppliers is currently in preparation.

\section{Acknowledgements}

We kindly acknowledge the Federal Ministry for the Environment, Nature Conservation and Nuclear Safety for funding of the project LithoRec II (project grant number: 16EM1025) in which the results in this manuscript could be achieved.

\section{References}

1 S. Pan, H. Tian, S. R. S. Dangal, Q. Yang, J. Yang, C. Lu, B. Tao, W. Ren and Z. Ouyang, Earth's Future, 2015, 3, 15-35.

2 Z. Morales-Reyes, J. M. Perez-Garcia, M. Moleon, F. Botella, M. Carrete, C. Lazcano, R. Moreno-Opo, A. Margalida, J. A. Donazar and J. A. Sanchez-Zapata, Sci. Rep., 2015, 5, 7811.

3 S. M. Rahman and G. A. Kirkman, Energ. Econ., 2015, 47, 129141.

4 J. Hansen, M. Sato, P. Kharecha, D. Beerling, R. Berner, V. Masson-Delmotte, M. Pagani, M. Raymo, D. L. Royer and J. C. Zachos, Open Atmos. Sci. J., 2008, 2, 217-231.

5 S. Fang and K. Fujimoto, Appl. Catal., A, 1996, 142, L1-L3.

6 N. S. Isaacs, B. O'Sullivan and C. Verhaelen, Tetrahedron, 1999, 55, 11949-11956.

7 T. Sakakura, J.-C. Choi, Y. Saito and T. Sako, Polyhedron, 2000, 19, 573-576.

8 S. Camy, J. S. Pic, E. Badens and J. S. Condoret, J. Supercrit. Fluids, 2003, 25, 19-32.

9 A. Buonerba, A. De Nisi, A. Grassi, S. Milione, C. Capacchione, S. Vagin and B. Rieger, Catal. Sci. Technol., 2015, 5, 118-123.

10 R. W. Schmitz, P. Murmann, R. Schmitz, R. Müller, L. Krämer, J. Kasnatscheew, P. Isken, P. Niehoff, S. Nowak, G.-V. Röschenthaler, N. Ignatiev, P. Sartori, S. Passerini, M. Kunze, A. Lex-Balducci, C. Schreiner, I. Cekic-Laskovic and M. Winter, Prog. Solid State Chem., 2014, 42, 65-84.

11 K. Xu, Chem. Rev., 2004, 104, 4303-4418.

12 K. Xu, Chem. Rev., 2014, 114, 11503-11618.

13 H. Schranzhofer, J. Bugajski, H. J. Santner, C. Korepp, K. C. Möller, J. O. Besenhard, M. Winter and W. Sitte, J. Power Sources, 2006, 153, 391-395.

$14 \mathrm{~J}$. O. Besenhard, M. W. Wagner, M. Winter, A. D. Jannakoudakis, P. D. Jannakoudakis and E. Theodoridou, J. Power Sources, 1993, 44, 413-420.

15 C. Dippel, R. Schmitz, R. Müller, T. Böttcher, M. Kunze, A. Lex-Balducci, G.-V. Röschenthaler, S. Passerini and M. Winter, J. Electrochem. Soc., 2012, 159, A1587-A1590.

16 M. Winter and P. Novák, J. Electrochem. Soc., 1998, 145, L27L30.

17 M. Winter, R. Imhof, F. Joho and P. Novák, J. Power Sources, 1999, 81-82, 818-823.

18 H. Buqa, R. I. R. Blyth, P. Golob, B. Evers, I. Schneider, M. V. Santis Alvarez, F. Hofer, F. P. Netzer, M. G. Ramsey, M. Winter and J. O. Besenhard, Ionics, 2000, 6, 172-179.

19 H. Buqa, P. Golob, M. Winter and J. O. Besenhard, J. Power Sources, 2001, 97-98, 122-125.

20 W. Xia, S. I. Vagin and B. Rieger, Chem.-Eur. J., 2014, 20, 15499-15504.

21 P. Altenbuchner, S. Kissling and B. Rieger, in Transformation and Utilization of Carbon Dioxide, ed. B. M. Bhanage and M. Arai, Springer, Berlin Heidelberg, 2014, pp. 163-200.

22 Q. Liu, L. Wu, R. Jackstell and M. Beller, Nat. Commun., 2015, 6, 3091.

23 D. R. Lide, CRC Handbook of Chemistry and Physics, 85 edn, 2004. 
24 M. C. Henry and C. R. Yonker, Anal. Chem., 2006, 78, 39093916.

25 E. Lack and H. Seidlitz, in Extraction of Natural Products Using Near-Critical Solvents, ed. M. B. King and T. R. Bott, Springer, Netherlands, 1993, pp. 101-139.

26 E. J. Beckman, Environ. Sci. Technol., 2002, 36, 347A-353A.

27 N. K. Sinha, D. E. Guyer, D. A. Gage and C. T. Lira, J. Agric. Food Chem., 1992, 40, 842-845.

28 J. P. Friedrich, G. R. List and A. J. Heakin, J. Am. Oil Chem. Soc., 1982, 59, 288-292.

29 E. Reverchon and F. Senatore, J. Agric. Food Chem., 1994, 42, 154-158.

30 M. J. van Bommel and A. B. de Haan, J. Non-Cryst. Solids, 1995, 186, 78-82.

31 A. C. Pierre and G. M. Pajonk, Chem. Rev., 2002, 102, 42434266.

32 D. Guironnet, I. Göttker-Schnetmann and S. Mecking, Macromolecules, 2009, 42, 8157-8164.

33 S. Moisan, V. Martinez, P. Weisbecker, F. Cansell, S. Mecking and C. Aymonier, J. Am. Chem. Soc., 2007, 129, 10602-10606.

34 S. E. Sloop, Patent No.: US 7.198.865 B2, 2007.

35 M. Winter and J. O. Besenhard, Chem. Unserer Zeit, 1999, 33, 320-332.

36 R. Wagner, N. Preschitschek, S. Passerini, J. Leker and M. Winter, J. Appl. Electrochem., 2013, 43, 481-496.

37 K. Tasaki, A. Goldberg and M. Winter, Electrochim. Acta, 2011, 56, 10424-10435.

38 H. J. Santner, C. Korepp, M. Winter, J. O. Besenhard and K. C. Möller, Anal. Bioanal. Chem., 2004, 379, 266-271.

39 C. Korepp, H. J. Santner, T. Fujii, M. Ue, J. O. Besenhard, K. C. Möller and M. Winter, J. Power Sources, 2006, 158, 578-582.

40 S. Dalavi, M. Xu, B. Ravdel, L. Zhou and B. L. Lucht, J. Electrochem. Soc., 2010, 157, A1113-A1120.

41 M. Winter, Z. Phys. Chem., 2009, 223, 1395.

42 D. Aurbach, M. L. Daroux, P. W. Faguy and E. Yeager, J. Electrochem. Soc., 1987, 134, 1611-1620.

43 E. Peled, D. Golodnitsky, G. Ardel and V. Eshkenazy, Electrochim. Acta, 1995, 40, 2197-2204.

44 E. Peled, D. Golodnitsky and G. Ardel, J. Electrochem. Soc., 1997, 144, L208-L210.

$45 \mathrm{H}$. Bryngelsson, M. Stjerndahl, T. Gustafsson and K. Edström, J. Power Sources, 2007, 174, 970-975.

46 P. Verma, P. Maire and P. Novák, Electrochim. Acta, 2010, 55, 6332-6341.

47 J. Vetter, P. Novák, M. R. Wagner, C. Veit, K. C. Möller, J. O. Besenhard, M. Winter, M. Wohlfahrt-Mehrens, C. Vogler and A. Hammouche, J. Power Sources, 2005, 147, 269-281.

48 H. Yoshida, T. Fukunaga, T. Hazama, M. Terasaki, M. Mizutani and M. Yamachi, J. Power Sources, 1997, 68, 311-315.

49 G. E. Blomgren, J. Power Sources, 1999, 81-82, 112-118.

50 U. Heider, R. Oesten and M. Jungnitz, J. Power Sources, 1999, 81-82, 119-122.
51 X. Zhang, P. N. Ross, R. Kostecki, F. Kong, S. Sloop, J. B. Kerr, K. Striebel, E. J. Cairns and F. McLarnon, J. Electrochem. Soc., 2001, 148, A463-A470.

52 K. Tasaki, K. Kanda, S. Nakamura and M. Ue, J. Electrochem. Soc., 2003, 150, A1628-A1636.

53 C. L. Campion, W. Li and B. L. Lucht, J. Electrochem. Soc., 2005, 152, A2327-A2334.

54 T. Sasaki, T. Abe, Y. Iriyama, M. Inaba and Z. Ogumi, J. Power Sources, 2005, 150, 208-215.

55 T. Sasaki, T. Abe, Y. Iriyama, M. Inaba and Z. Ogumi, J. Electrochem. Soc., 2005, 152, A2046-A2050.

56 L. Gireaud, S. Grugeon, S. Pilard, P. Guenot, J.-M. Tarascon and S. Laruelle, Anal. Chem., 2006, 78, 3688-3698.

57 G. Gachot, S. Grugeon, M. Armand, S. Pilard, P. Guenot, J.-M. Tarascon and S. Laruelle, J. Power Sources, 2008, 178, 409-421.

58 G. Gachot, P. Ribière, D. Mathiron, S. Grugeon, M. Armand, J.-B. Leriche, S. Pilard and S. Laruelle, Anal. Chem., 2011, 83, 478-485.

59 L. Terborg, S. Nowak, S. Passerini, M. Winter, U. Karst, P. R. Haddad and P. N. Nesterenko, Anal. Chim. Acta, 2012, 714, 121-126.

60 L. Terborg, S. Weber, F. Blaske, S. Passerini, M. Winter, U. Karst and S. Nowak, J. Power Sources, 2013, 242, 832-837.

61 B. Vortmann, S. Nowak and C. Engelhard, Anal. Chem., 2013, 85, 3433-3438.

62 L. Terborg, S. Weber, S. Passerini, M. Winter, U. Karst and S. Nowak, J. Power Sources, 2014, 245, 836-840.

63 M. Grützke, V. Kraft, W. Weber, C. Wendt, A. Friesen, S. Klamor, M. Winter and S. Nowak, J. Supercrit. Fluids, 2014, 94, 216-222.

64 V. Kraft, M. Grützke, W. Weber, M. Winter and S. Nowak, J. Chromatogr. A, 2014, 1354, 92-100.

65 M. Grützke, V. Kraft, B. Hoffmann, S. Klamor, J. Diekmann, A. Kwade, M. Winter and S. Nowak, J. Power Sources, 2015, 273, 83-88.

66 C. Schultz, V. Kraft, M. Pyschik, S. Weber, F. Schappacher, M. Winter and S. Nowak, J. Electrochem. Soc., 2015, 162, A629-A634.

67 W. Weber, V. Kraft, M. Grützke, M. Winter and S. Nowak, J. Chromatogr. A, 2015, 1394, 128-136.

68 A. W. Golubkov, D. Fuchs, J. Wagner, H. Wiltsche, C. Stangl, G. Fauler, G. Voitic, A. Thaler and V. Hacker, RSC Adv., 2014, 4, 3633-3642.

69 Y. Fu, S. Lu, K. Li, C. Liu, X. Cheng and H. Zhang, J. Power Sources, 2015, 273, 216-222.

70 M. Reichert, J. Haetge, D. Berghus, C. Wendt, V. Meier, U. Rodehorst, S. Passerini, F. Schappacher and M. Winter, ECS Trans., 2014, 61, 87-103.

71 D. Aurbach, B. Markovsky, A. Rodkin, M. Cojocaru, E. Levi and H.-J. Kim, Electrochim. Acta, 2002, 47, 1899-1911.

72 T. A. Immel, M. Grützke, A.-K. Späte, U. Groth, P. Öhlschlager and T. Huhn, Chem. Commun., 2012, 48, 5790-5792.

73 P. W. Atkins and J. d. Paula, Kurzlehrbuch Physikalische Chemie, 2005. 
74 S. E. Sloop, J. K. Pugh, S. Wang, J. B. Kerr and K. Kinoshita, Electrochem. Solid-State Lett., 2001, 4, A42-A44.

75 S. Castillo, F. Ansart, C. Laberty-Robert and J. Portal, J. Power Sources, 2002, 112, 247-254.

76 M. J. Lain, J. Power Sources, 2001, 97-98, 736-738.
77 S. Krüger, C. Hanisch, A. Kwade, M. Winter and S. Nowak, J. Electroanal. Chem., 2014, 726, 91-96.

78 Y. Wang, Z.-S. Feng, J.-J. Chen and C. Zhang, Mater. Lett., 2012, 71, 54 . 